\title{
Endocrine Alterations Associated with Extended Time Interval Between Estrus and Ovulation in High-Yield Dairy Cows
}

\author{
A. Bloch, ${ }^{\star}$ Y. Folman, $†$ M. Kaim, $†$ Z. Roth,* R. Braw-Tal,† and D. Wolfenson*1 \\ *Department of Animal Science, Faculty of Agriculture, The Hebrew University, Rehovot 76100, Israel \\ †Institute of Animal Science, Agricultural Research Organization, Bet-Dagan 50250, Israel
}

\begin{abstract}
Short fertile half-lives of the male and female gametes in the female tract necessitate accurate timing of artificial insemination. We examined the possible association between extension of the estrus to ovulation (E-O) interval and alterations in concentrations of estradiol, progesterone, and the preovulatory LH surge before estrus and ovulation. High-yielding Holstein cows ( $\mathrm{n}=74$ from a total of 106 ) were synchronized and were examined around the time of the subsequent estrus. They were observed continuously for estrual behavior. Blood samples were collected before and after estrus, and ultrasound checks for ovulation were made every $4 \mathrm{~h}$. About three-quarters of the cows exhibited short (but normal) E-O intervals of 22 to $25 \mathrm{~h}(25 \%)$ or normal intervals of 25 to $30 \mathrm{~h}$ (47\%); $17 \%$ of them displayed a long (but normal) E-O interval of 31 to 35 $\mathrm{h}$, and about $10 \%$ exhibited a very long E-O interval of 35 to $50 \mathrm{~h}$. Extended E-O interval comprised estrusto-LH surge and LH surge-to-ovulation intervals that were both longer than normal. Pronounced changes in hormonal concentrations were noted before ovulation in the very long E-O interval group of cows: progesterone and estradiol concentrations were reduced, and the preovulatory LH peak surge was markedly less than in the other 3 groups. Postovulation progesterone concentrations during the midluteal phase were lesser in the very long and the long E-O interval groups compared with those in the short and normal interval groups. Season, parity, milk yield, and body condition did not affect the estrus to LH surge, LH surge to ovulation, and E-O intervals. The results indicate an association between preovulatory-reduced estradiol concentrations and a small preovulatory LH surge, on the one hand, and an extended E-O interval, on the other hand. Delayed ovulation could cause nonoptimal timing of AI, a less than normal preovulatory LH surge that may be associated with suboptimal maturation of the oocyte
\end{abstract}

Received March 30, 2006.

Accepted June 26, 2006.

${ }^{1}$ Corresponding author: wolf@agri.huji.ac.il before ovulation, or reduced progesterone concentrations before and after ovulation. All may be factors associated with poor fertility in cows with a very long E-O interval.

Key words: estrus, ovulation, luteinizing hormone surge, dairy cow

\section{INTRODUCTION}

Delayed ovulation in cows following estrus minimizes the chances of successful fertilization. The short fertile half-life of bovine gametes restricts the period during which fertilization can occur (Dransfield et al., 1998; Nebel et al., 2000). Fertilization rate of the oocyte decreases significantly 8 to $12 \mathrm{~h}$ postovulation, and insemination 25 to $40 \mathrm{~h}$ before ovulation is associated with a significant decrease in conception rates (Hunter, 1994). In most studies, mean intervals between onset of estrus and ovulation (E-O) in beef and dairy cattle ranged from 23 to $33 \mathrm{~h}$ (Renger et al., 1978; Mikeska and Williams, 1988; Lemaster et al., 1999), and the mean was reported to be about $27 \mathrm{~h}$ in lactating dairy cows (Walker et al., 1996).

Wide variation among E-O intervals of individual cows or heifers in older studies was attributed to inadequate frequencies of detecting estrus and palpation of ovaries to determine ovulation. Even in more recent studies, however, in which modern electronic devices were used to detect the onset of estrus, and in which the ovulation time was more frequently monitored by ultrasonography, a wide variation in E-O intervals was reported. For example, Walker et al. (1996) reported that $78 \%$ of lactating cows ovulated within $40 \mathrm{~h}$ of the onset of estrus, but that $22 \%$ had not ovulated by 40 h. In another recent study of lactating Holstein cows, a mean E-O interval of $30 \mathrm{~h}$, with a range from 18.5 to $48.5 \mathrm{~h}$ was reported (Roelofs et al., 2005). A mean interval of $28 \mathrm{~h}$ (ranging from 12 to $36 \mathrm{~h}$ ) from visual estrus to ovulation was noted for Bos indicus cows (Cavalieri et al., 1997). Notably, mean E-O intervals and ranges were similar for cows exhibiting spontaneous estrus and for those in which estrus was induced by $\mathrm{PGF}_{2 \alpha}$ (Walker et al., 1996). A wide variation among E-O intervals was recorded for heifers as well; $92 \%$ of Holstein 
heifers ovulated within $36 \mathrm{~h}$ of the onset of estrus and $8 \%$ between 36 and $48 \mathrm{~h}$ after estrus (Hernandez-Ceron et al., 1993). Lemaster et al. (1999) reported a mean interval of $26 \mathrm{~h}$ and a range from 11 to $71 \mathrm{~h}$ in crossbred Brahman heifers.

Despite extensive documentation over the years that confirms large variation among $\mathrm{E}-\mathrm{O}$ intervals of individual cows, the possible associations between extended E-O intervals and endocrine traits are poorly documented. A single study by Saumande and Humblot (2005) reported a negative correlation between the preovulatory peak in estradiol concentrations and duration of the estrus-LH peak and E-O intervals. They hypothesized an ovarian control of those intervals that was related to a negative correlation between the size of the preovulatory follicle and the E-O interval. The endocrine milieu, however, that is associated with delayed ovulation and extended E-O interval has not been characterized. The present study characterized groups of cows that exhibited short, normal, long, or very long E$\mathrm{O}$ intervals. We focused on the exceptional group of cows that exhibited a very long E-O interval because a long E-O interval minimizes the chances of those cows conceiving. We examined the possibility that the abnormally large E-O interval in a group of high-yielding cows was associated with alterations in steroid and gonadotropin concentrations; namely, progesterone concentrations during the preceding luteal phase, estradiol concentrations before estrus, and LH concentrations at the preovulatory peak.

\section{MATERIALS AND METHODS}

\section{Cows}

Holstein cows in their first to fifth lactations were used. The experiment, which was designed with 9 clusters of cows grouped according to their calving dates, was performed during spring (March to May), summer (July to August), and fall (October to November). Cows were kept in an open shed with access to an adjacent yard. During summer, a sprinkling and ventilation cooling system was used (Flamenbaum et al., 1986). Maximum and minimum air temperature and relative humidity were as follows: spring, 22.9 and $12.6^{\circ} \mathrm{C}, 67$ and $52 \%$; summer, 32.7 and $22.5^{\circ} \mathrm{C}, 69$ and $53 \%$; and fall, 27 and $15^{\circ} \mathrm{C}, 68$ and $52 \%$, respectively. Cows were fed ad libitum a TMR containing $1.74 \mathrm{Mcal}$ of $\mathrm{NE}_{\mathrm{L}}$ per $\mathrm{kg}$ of DM and $17 \%$ protein. Cows were milked 3 times daily. Monthly milk yields were recorded, and percentages of fat and protein were determined by the central laboratories of the Israeli Cattle Breeding Association. Body condition score on a 5-point scale was determined (Wildman et al., 1982) by the same person immediately after calving and at 70 DIM. The experiment was conducted in accordance with the guidelines of the local ethics committee.

\section{Experimental Protocol}

Estrus was synchronized in lactating cows at about 50 to $60 \mathrm{~d}$ postpartum by inserting an intravaginal insert containing progesterone (CIDR, Eazi-Breed, Hamilton, NZ) for $9 \mathrm{~d}$ and treating cows with $\mathrm{PGF}_{2 \alpha}$ analog (Cloprostenol, Estrumate $500 \mu \mathrm{g}$ i.m., Coopers, Berkhamsted, UK) $2 \mathrm{~d}$ before removal of the insert. To prevent any possible effects of the synchronization procedure [e.g., the persistent follicle syndrome that could be induced in cows that receive exogenous progesterone in the absence of endogenous corpus luteum $\mathbf{C L}$; Smith and Stevenson, 1995)], we began the experimental examinations during the estrus subsequent to the synchronized estrus (about 70 to 80 DIM), 3 wk after terminating the initial estrus-synchronization protocol. A total of 106 cows (one-third primiparous and twothirds multiparous) that had been subjected to the synchronization protocol were observed for estrus 4 times daily at the time they were expected to manifest estrus. Cows that were not observed to be in estrus within $4 \mathrm{~d}$ after CIDR removal (during the initial synchronization) were treated with a single dose of $\mathrm{PGF}_{2 \alpha} 20 \mathrm{~d}$ after CIDR insert removal. Thus, 2 groups of cows were included in the experiment: those that manifested estrus following initial synchronization and those that did not; the latter were treated with $\mathrm{PGF}_{2 \alpha}$. A 5-d period of intensive experimental examinations began $20 \mathrm{~d}$ after the synchronized estrus, or $36 \mathrm{~h}$ after $\mathrm{PGF}_{2 \alpha}$. Of the 106 cows subjected to the initial synchronization protocol, 74 cows (70\%) manifested estrus about $3 \mathrm{wk}$ after the initial protocol within the period of continuous observations and were included in the study. Of these, 47 cows exhibited spontaneous estrus and 27 exhibited $\mathrm{PGF}_{2 \alpha}$-induced estrus.

\section{Data Collection}

During the experiment, visual indications of estrus were monitored continuously ( $24 \mathrm{~h}$ daily during $5 \mathrm{~d}$ ) by a team of 2 people. Exact onset of estrus was determined by recording the time of the first standing event, providing that the individual cow went on to manifest several standing events and exhibited other behavioral signs typical of a cow in estrus. Transrectal ultrasonography of the ovaries was conducted by using a 7.5- $\mathrm{MHz}$ probe (Aloka 210, Tokyo, Japan). It was carried out once at the beginning of the 5-d period to detect the preovulatory follicle and to confirm that the ovarian structures were typical of that found in a normal follicular phase. Commencing $20 \mathrm{~h}$ after standing estrus, ultrasonography 
of the ovaries was carried out every $4 \mathrm{~h}$ until ovulation was detected, or until $50 \mathrm{~h}$ after the onset of estrus for cows that failed to ovulate by that time. Based on the 4-h interval of ultrasonographic monitoring, the time of ovulation was considered to be $2 \mathrm{~h}$ before the time when ovulation could be discerned (Kaim et al., 2003). From $10 \mathrm{~d}$ before expected estrus, blood samples were collected every other day for progesterone determination. During the 5-d period of continuous observation, blood samples for later estradiol determination were collected every $8 \mathrm{~h}$ until the onset of estrus. From the onset of estrus, samples for LH determination were collected every $3 \mathrm{~h}$ for $24 \mathrm{~h}$. Following ovulation, blood samples for progesterone determination were collected every other day from d 1 to 20 of the cycle.

\section{Hormonal Determinations}

Plasma samples for estradiol determination were extracted with diethyl ether as described previously (Badinga et al., 1992), and extracted samples were analyzed by RIA as validated in our laboratory (Shaham-Albalancy et al., 2000). The antibody (Diagnostic Products Corp., Los Angeles, CA) did not cross-react significantly with other major steroids. Assay sensitivity was $0.5 \mathrm{pg} /$ $\mathrm{mL}$, and the intra- and interassay coefficients of variation were 8.5 and $9.5 \%$, respectively. Plasma progesterone concentrations of unextracted samples were analyzed by using a solid-phase radioimmunoassay kit (Diagnostic Product Corp.) against a standard curve prepared in our laboratory by dissolving progesterone in plasma from an ovariectomized cow, as described previously (Shaham-Albalancy et al., 2000). Assay sensitivity was $0.2 \mathrm{ng} / \mathrm{mL}$ and the intra- and interassay coefficients of variations were 3.9 and $8.6 \%$, respectively. Plasma LH concentrations were measured by enzyme immunoassay with a biotin-streptavidin amplification and validated for bovine plasma as described previously (Mutayoba et al., 1990). The procedure was validated recently in our laboratory (Kaim et al., 2003). Intra- and interassay coefficients of variation in the assay were 8.5 and $10.6 \%$, respectively, and its sensitivity was $7.8 \mathrm{pg} / \mathrm{well}$. Values for LH are expressed in nanograms of bovine LH (USDA bLH-B-6) per milliliter.

\section{Data Analyses}

Data were analyzed by ANOVA (procedure GLM; SAS Inst. Inc., Cary NC). Cows were sorted into 4 groups according to the E-O interval range (Figure 1A) and on the basis of previous publications, as follows: The first group, with intervals between 22 and $25 \mathrm{~h}$, was designated as having a short (but normal) interval
(Figure 1B). The second group, with an E-O interval of 26 to $30 \mathrm{~h}$ (most common range reported in the literature), was designated as normal (Walker et al., 1996; Rajamahendran et al., 1998, Roelofs et al., 2005). The third group comprised cows having E-O intervals between 31 and $35 \mathrm{~h}$; this range was considered long (but normal), and the group was designated as having a long interval. Finally, a fourth group of cows with an E-O interval greater than $36 \mathrm{~h}$ was designated as having a very long interval (Figure 1B). Sorting the experimental cows into 4 groups according to the $\mathrm{E}-\mathrm{O}$ interval range enabled us to efficiently characterize the extended EO interval syndrome. This syndrome has been described (Walker et al., 1996), but little is known about its endocrine characteristics. This syndrome was represented in the present study by the group of cows with a very long E-O interval. We tested the effects of the type of estrus (spontaneous or $\mathrm{PGF}_{2 \alpha}$-induced) on the distribution of cows among the 4 groups, and on hormone (estradiol, progesterone, and LH) concentrations. On the basis of these analyses, type of estrus was ignored in subsequent analyses because it had no significant effect on any outcome of interest, and the results for cows exhibiting the 2 types of estrus were combined, as in studies by other workers (Walker et al., 1996). Data related to intervals from estrus to the $\mathrm{LH}$ surge, the LH surge to ovulation, and the E-O intervals, peak concentration of the LH surge, milk yield and composition, and BCS were analyzed by one-way ANOVA. Effects of season and parity on distribution of cows among the $4 \mathrm{E}-\mathrm{O}$ interval groups was tested by $\chi^{2}$. The statistical models for hormonal concentrations included the effects of E-O interval groups, cows (within a group), time (hours or days from estrus), milk yield, body condition, parity, and season.

\section{RESULTS}

\section{Length and Distribution of Intervals Between Estrus, LH Surge, and Ovulation}

Distribution of the E-O interval ranged from 22 to at least $50 \mathrm{~h}$ (Figure 1A). The group having normal E-O intervals ( 26 to $30 \mathrm{~h}$ ) comprised about half (47\%) of the examined cows (Figure 1B). The group with short E-O interval ( 22 to $25 \mathrm{~h}$ ) comprised $25 \%$ of the cows. These 2 groups taken together represented nearly three-quarters of the cows that exhibited short or normal E-O intervals of 22 to $30 \mathrm{~h}$. The group with long E-O intervals ( 31 to $35 \mathrm{~h}$ ) comprised $17 \%$ of the cows. The fourth group with very long E-O intervals ( $>36 \mathrm{~h}$ ) comprised 7 cows (i.e., $10 \%$ of the experimental cow population examined in this study). Three cows of this group failed to ovulate by $50 \mathrm{~h}$ after the onset of estrus (scanning 


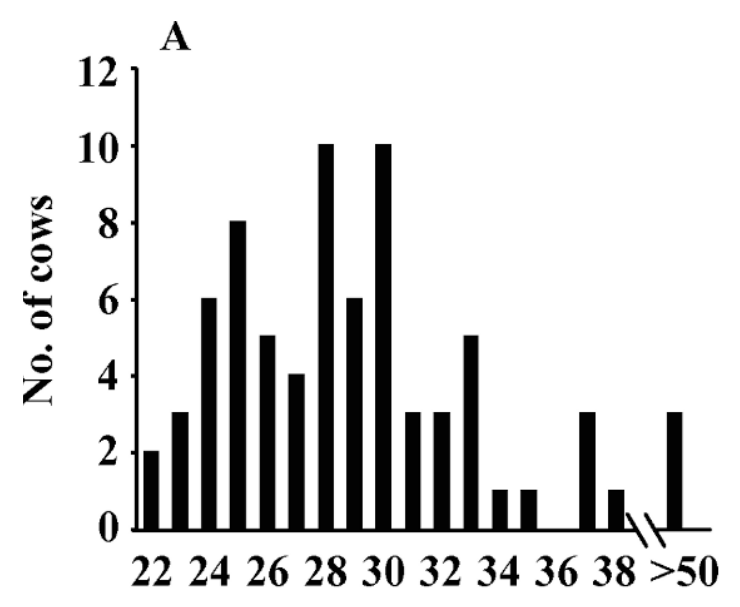

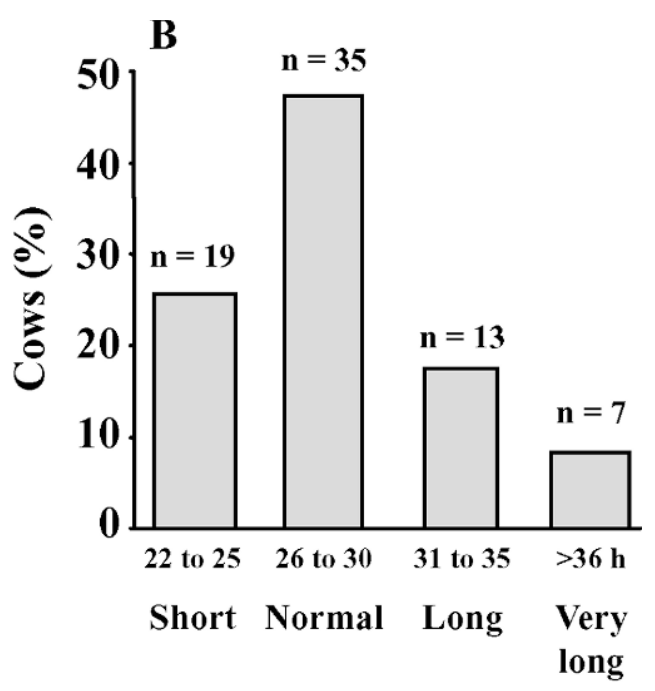

\section{Estrus-ovulation interval (h)}

Figure 1. A) Distribution of the experimental cow population $(\mathrm{n}=74)$ sorted by estrus to ovulation intervals. Individual values are subject to an estimated error of $\pm 2 \mathrm{~h}$. B) Distribution (\%) of the experimental cow population among 4 groups of cows, sorted according to their range of estrus-ovulation interval into short, normal, long, and very long intervals.

was not continued after $50 \mathrm{~h}$ ), and these 3 cows were designated as having an E-O interval of at least $50 \mathrm{~h}$.

Further evaluation of these 3 cows clearly indicated that each eventually ovulated and subsequently developed a CL. First, ultrasound examinations performed twice, at about 8 to $10 \mathrm{~d}$ and 13 to $15 \mathrm{~d}$ after estrus, indicated that in all 3 cows, the largest follicle disappeared and a new, normal-size CL was present in the expected ovary. These CL were much larger than the average size (about $17 \mathrm{~mm}$ in diameter) of corresponding ovulatory follicles, and their average calculated volume (about $7,300 \mathrm{~mm}^{3}$ ) was within normal range for $\mathrm{CL}$ at that stage of the cycle. Second, progesterone concentrations in 2 of these cows exhibited a normal postovulatory pattern that did not differ from those shown in Figure 3. In the third cow, the progesterone pattern of increase was similar, but was delayed by $4 \mathrm{~d}$. Individual midluteal-phase concentrations of progesterone of the 3 cows were $4.8,5.1$, and $7.5 \mathrm{ng} / \mathrm{mL}$. They were typical and within the normal range for high-yielding cows and were indicative of steroidogenically active CL. Collectively, these findings confirmed that the 3 cows that failed to ovulate by $50 \mathrm{~h}$ after the onset of estrus did so eventually.

The mean interval between the onset of estrus and the peak LH surge was later $(P<0.01)$ at $9 \mathrm{~h}$ in the very long E-O interval group, compared with $3.5 \mathrm{~h}$ in the normal interval group (Table 1). Interval from the LH surge to ovulation was greater $(P<0.01)$ by about $4 \mathrm{~h}$ in the long and very long groups than in the normal group (Table 1).
Milk, milk fat, and protein yields during the experimental period did not differ among the 4 experimental groups (Table 2). Similarly, BCS at calving or during the experimental period (70 DIM) did not differ among the 4 experimental groups (Table 2). Effects of season on distribution of cows among the $4 \mathrm{E}-\mathrm{O}$ interval groups were minor and not statistically significant. Likewise, we did not find any significant effect of parity on distribution of cows among E-O interval groups (neither primiparous compared with multiparous cows, nor comparisons among multiparous cows with differing numbers of lactations had any effect on the above). It is noteworthy that the time of onset of estrus (day or night) did not have any significant effect on the E-O interval.

Ultrasound examination of the ovaries at the beginning of the 5-d period of intensive experimental examinations indicated that, similar to experimental cows with a normal E-O interval, the ovaries of the cows with a very long E-O interval exhibited a normal appearance, typical of the follicular phase, consisting of 1 or 2 large follicle(s), a few medium-size follicles, and a regressing CL. Likewise, later ultrasound examinations (during the 5-d period, intended to determine the time of ovulation) confirmed the presence of a dominant follicle and a CL in an advanced stage of regression. All experimental cows ovulated, as indicated by the growth of new CL and elevated concentrations of plasma progesterone. Proportions of cows having spontaneous or induced estrus (63 and $36 \%$, respectively) were similar in the short, normal, long, and very long E-O interval groups. 
Table 1. Intervals between estrus and LH surge, LH surge and ovulation, and estrus and ovulation in the 4 groups of cows, sorted by range of intervals between estrus and ovulation (mean $\pm \mathrm{SE}$ )

\begin{tabular}{lrrrrr}
\hline & \multicolumn{3}{c}{ Interval from estrus to ovulation groups } & \\
\cline { 2 - 5 } & \multicolumn{1}{c}{ Short } & \multicolumn{1}{c}{ Normal } & \multicolumn{1}{c}{ Long } & \multicolumn{1}{c}{ Very long } & \multicolumn{1}{c}{ Overall } \\
\hline Estrus to LH surge, h & $0.0 \pm 0.6^{\mathrm{a}}$ & $3.5 \pm 0.5^{\mathrm{b}}$ & $3.9 \pm 0.8^{\mathrm{b}}$ & $9.0 \pm 3.5^{\mathrm{c}}$ & $2.8 \pm 0.4$ \\
LH surge to ovulation, h & $24.0 \pm 0.5^{\mathrm{a}}$ & $24.7 \pm 0.5^{\mathrm{a}}$ & $28.4 \pm 0.8^{\mathrm{b}}$ & $28.2 \pm 3.2^{\mathrm{b}}$ & $25.5 \pm 0.5$ \\
Estrus to ovulation, h & $23.9 \pm 0.2^{\mathrm{a}}$ & $28.2 \pm 0.2^{\mathrm{b}}$ & $32.3 \pm 0.4^{\mathrm{c}}$ & $42.6 \pm 2.6^{\mathrm{d}}$ & $28.6 \pm 0.6$ \\
\hline
\end{tabular}

${ }^{\mathrm{a}-\mathrm{d}}$ Means of the 4 interval groups within a row having different superscript letters differ $(P<0.01)$.

Among the last group, 4 and 3 of 7 cows (57 and $42 \%$, respectively) exhibited natural and induced estrus, respectively.

\section{Hormonal Concentrations}

A weak correlation was detected between the E-O interval and mean progesterone concentration during the 10- $\mathrm{d}$ period before the examined estrus $(\mathrm{r}=-0.27$; $P<0.04)$. Correlations between the E-O interval and peak estradiol concentration before estrus $(\mathrm{r}=-0.17$; $P<0.15)$ or peak LH surge concentration $(\mathrm{r}=-0.21$; $P<0.09$ ) were slight and not statistically significant. Further analyses, described below, were applied after the experimental cows had been sorted into 4 groups according to their E-O interval range.

Progesterone concentrations before the examined estrus are presented in Figure 2. The very long interval group exhibited reduced $(P<0.05)$ progesterone concentrations during the 10-d period before estrus than those in the short, normal, and long groups $(2.8 \pm 0.6$ vs. 4.2 $\pm 0.2 \mathrm{ng} / \mathrm{mL}$; pooled value for the latter 3 groups). Luteal regression in the very long interval group started earlier than in the other 3 groups, as manifested in the decline in progesterone on $d-5$ rather than on $d-3$ (Figure 2). As in the cycle preceding ovulation, progesterone concentration curves during the midluteal phase of the cycle following the examined ovulation (d 11 to 18 ; Figure 3$)$ were less $(P<0.04)$ in the very long inter- val group, and also in the long interval group, than in the short or normal groups ( $4.4 \mathrm{vs} .5 .6 \mathrm{ng} / \mathrm{mL}$ ). As in the preceding cycle, luteolysis started earlier in the groups with longer intervals than in those with short or normal intervals (Figure 3). Cycle durations were similar in the 4 groups of cows (Table 2).

Concentrations of estradiol during the follicular phase before the LH surge were less $(P<0.06)$ in the very long interval group than in the other 3 groups (Figure 4). Interestingly, mean diameters of the preovulatory follicles on the day before ovulation did not differ between the short, normal, long, and very long interval groups $(16.8 \pm 0.6,17.0 \pm 0.3,16.3 \pm 0.6$, and $17.7 \pm 0.5$ $\mathrm{mm}$, respectively).

Concentrations of $\mathrm{LH}$ at the time of the preovulatory surge were normalized to the peak concentration of the LH surge in each of the 4 groups of cows. As shown in Figure 5, the peak of $\mathrm{LH}$ surge concentration in the very long interval group was about 2.5 times less $(P<$ $0.03)$ than those in the other 3 groups. Mean peak LH surge concentration in the short, normal, and long groups was $10 \mathrm{ng} / \mathrm{mL}$, with no significant difference among them, and that in the very long interval group was $4 \mathrm{ng} / \mathrm{mL}$ (Figure 5).

\section{DISCUSSION}

Short fertile half lives of the oocyte after ovulation and of the spermatozoa in the female tract (Hunter,

Table 2. Milk and milk component yields during the experimental period, BCS, and cycle durations of the 4 groups of experimental cows, sorted by range of intervals between estrus and ovulation (mean $\pm \mathrm{SE})^{1}$

\begin{tabular}{lcccc}
\hline & \multicolumn{3}{c}{ Interval from estrus to ovulation groups } \\
\cline { 2 - 5 } & \multicolumn{1}{c}{ Short } & Normal & Long & Very long \\
\hline Milk yield, kg/d & $47.1 \pm 2.8$ & $43.9 \pm 1.4$ & $44.7 \pm 2.3$ & $47.1 \pm 3.5$ \\
Milk fat, kg/d & $1.51 \pm 0.11$ & $1.55 \pm 0.06$ & $1.46 \pm 0.11$ & $1.67 \pm 0.17$ \\
Milk protein, kg/d & $1.35 \pm 0.08$ & $1.29 \pm 0.03$ & $1.30 \pm 0.07$ & $1.38 \pm 0.08$ \\
BCS at calving & $3.3 \pm 0.1$ & $3.1 \pm 0.1$ & $3.2 \pm 0.1$ & $3.3 \pm 0.2$ \\
BCS at 70 DIM & $2.6 \pm 0.1$ & $2.5 \pm 0.1$ & $2.5 \pm 0.1$ & $2.4 \pm 0.1$ \\
Estrous cycle length, d & $22.0 \pm 0.6$ & $21.6 \pm 0.4$ & $22.2 \pm 0.5$ & $22.3 \pm 0.8$ \\
\hline
\end{tabular}

${ }^{1}$ Means did not differ among the 4 groups of cows.

${ }^{2}$ Mean percentages of milk fat and milk protein were $3.40 \pm 0.06 \%$ and $2.92 \pm 0.02 \%$, respectively. 


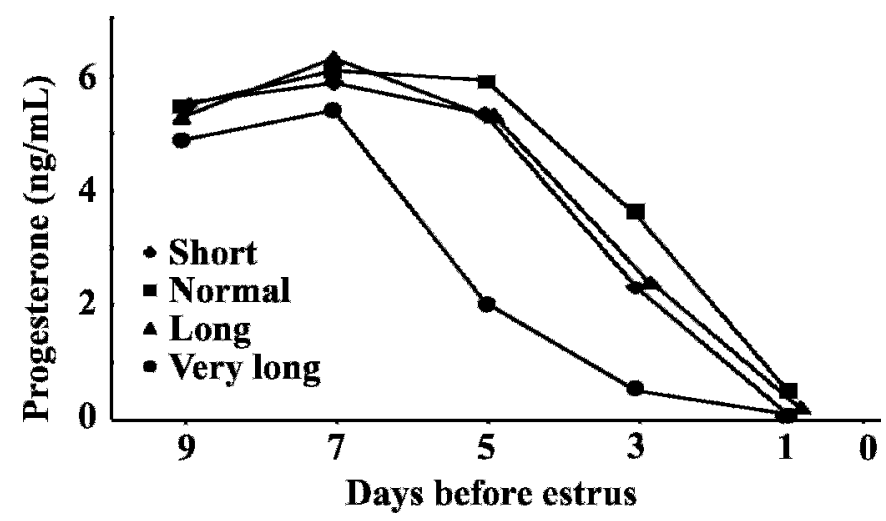

Figure 2. Concentrations of plasma progesterone in the 4 groups of cows sorted by estrus-ovulation (E-O) interval during $10 \mathrm{~d}$ before estrus. Concentrations in the very long E-O interval group were less $(P<0.03)$ than in the other groups before estrus. Pooled SEM $=0.73$.

1994) narrow the optimal time window for maximal fertilization. In the present study, we characterized an abnormal group of cows that exhibited delayed ovulation and an extended E-O interval. This group formed one-tenth of the total number of cows. The present study sheds light on changes in the endocrine milieu that may be partly associated with reduced fertility in cows having extended E-O intervals. These changes included low concentrations of progesterone and estradiol and a low LH surge before ovulation.

The proportion of cows found to exhibit an extended E-O interval varies among studies. In the present study, the very long interval group comprised $10 \%$ of

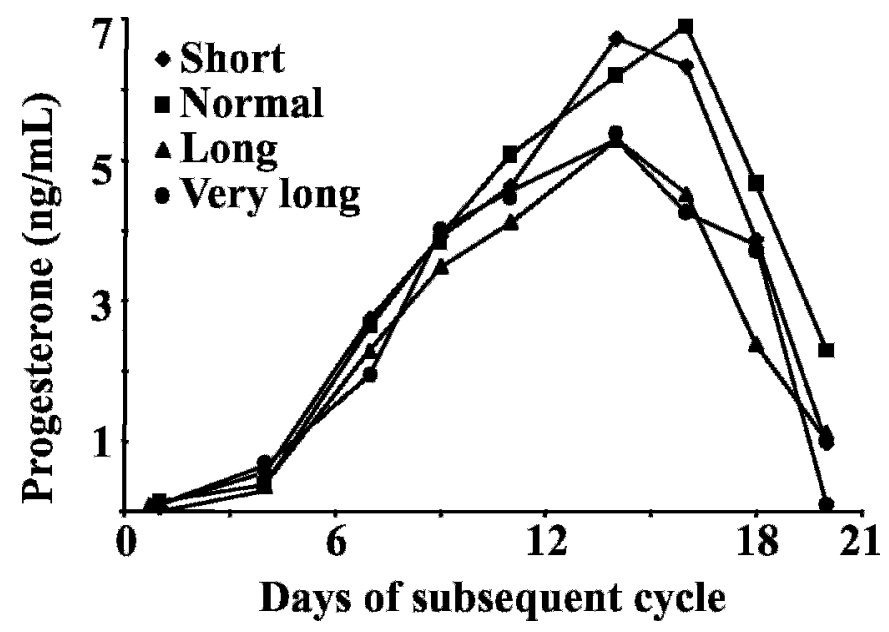

Figure 3. Concentrations of plasma progesterone in the 4 groups of cows sorted by estrus-ovulation (E-O) interval during the cycle following ovulation. Data were normalized according to time of ovulation. Concentrations in long and very long E-O interval groups during midluteal phase were less $(P<0.04)$ than in the other groups. Pooled $\mathrm{SEM}=0.69$

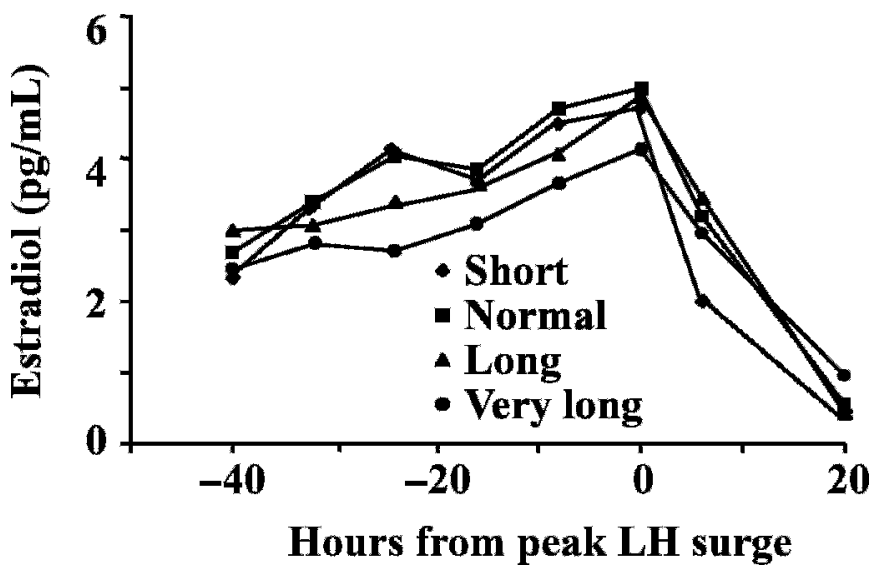

Figure 4. Concentrations of plasma estradiol before ovulation in the 4 groups of cows sorted by estrus-ovulation (E-O) interval. Concentrations in the very long E-O interval group were less $(P<$ 0.06 ) than in the other groups. Pooled SEM $=0.49$.

the experimental cows, whereas in earlier studies it ranged from $8 \%$ in heifers (Hernandez-Ceron et al., 1993 ) to 15 to $22 \%$ in cows (Walker et al., 1996; Roelofs et al., 2005). The number of cows used in the present study provided a sufficiently large study population to support adequate statistical analyses. Continuous observation for estrus and frequent ultrasonographic monitoring enabled us to accurately determine the time of ovulation and the E-O interval for each cow, with an estimated error of $\pm 2 \mathrm{~h}$. In this respect, repeated rectal ultrasound examinations of dairy cows (as performed herein for determination of ovulation) did not alter the timing of estrus, durations of the E-O, and estrus to

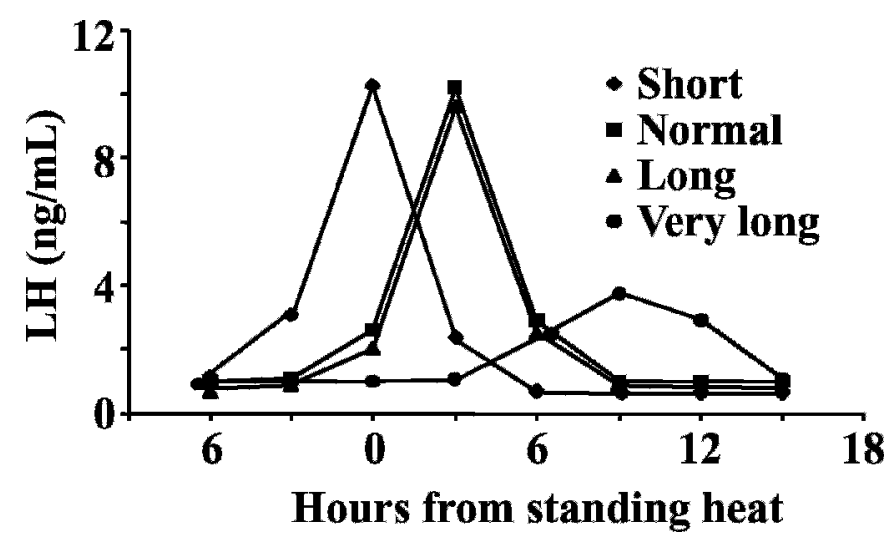

Figure 5. Concentrations of plasma preovulatory LH surges in the 4 groups of cows sorted by estrus to ovulation (E-O) interval. Data were normalized according to peak $\mathrm{LH}$ in each group and are presented relative to the onset of estrus. Concentration of peak LH in the very-long E-O interval group was less $(P<0.01)$ than in the other groups. Pooled SEM $=0.68$. 
LH surge intervals, or the periovulatory concentrations of plasma steroids and LH (Roelofs et al., 2004).

The present study provides clear evidence that an extended E-O interval is associated with alterations in the concentrations of progesterone, estradiol, and $\mathrm{LH}$ surge in plasma. We found markedly different hormonal profiles in the extended E-O interval (very long E-O) group of cows than in the other 3 "normal" groups of cows. Saumande and Humblot (2005) found correlations between the preovulatory estradiol concentrations, the preovulatory follicle size, and the E-O interval. The present study, however, indicated that alterations in progesterone, estradiol, and LH surge concentrations before ovulation were evident only in cows with an extended E-O interval and not in the entire population of experimental cows. Although preovulatory follicle size in the very long E-O interval group did not differ from that in the normal interval groups, the reduced estradiol concentrations found in the former group were presumably due to development of a less steroidogenically active, preovulatory follicle. Reduced estradiol concentrations before estrus probably delayed the LH surge so that the estrus to LH surge interval was about $6 \mathrm{~h}$ longer in the very long interval group than in the normal interval group. Although it is generally accepted that most of the variation in the E-O interval can be attributed to variation in the estrus to LH surge interval (Saumande and Humblot, 2005), the present findings indicate that extension of the interval from LH surge to ovulation also contributed to that variation.

The markedly small preovulatory LH surge amplitude in the very long E-O group, which is reported for the first time in our study, could be related to low preovulatory estradiol concentrations. Indeed, we found a close association between low preovulatory estradiol concentrations and low-amplitude LH surges, which occurred only in the group of cows with a very long EO interval, and not among the entire population of cows. A less-than-normal LH surge peak could be associated with a delayed timing of ovulation, which caused, in turn, a significant 4-h extension of the LH surge to ovulation interval in the very long E-O interval group. This interpretation is strengthened by findings that induction of stress in sheep or cows by endotoxin (LPS) administration during the follicular phase or at the onset of estrus was associated with a decline in the LH surge amplitude and with delayed ovulation (Battaglia et al., 1999; Suzuki et al., 2001; Lavon et al., 2004). It should be mentioned, however, that a similar extension of the LH surge to ovulation interval also was noted in the long E-O interval group. Collectively, the present findings suggest that extension of the E-O interval is probably associated with 1) delayed secretion of the preovulatory LH surge relative to onset of estrus, possibly because of inadequate concentrations of estradiol; and 2) extension of the time between the LH surge and the occurrence of ovulation, possibly because of limited secretion during the preovulatory LH surge.

Luteal insufficiency in cows with a very long E-O interval, which is reported here for the first time, is characterized not only by low progesterone concentration curves, but also by an earlier luteal regression before estrus. The reason for this insufficiency is not yet clear. Interestingly, the reduced luteal progesterone concentration curve does not seem to be a random event because this pattern was repeated in the next cycle after ovulation. Low progesterone curves could result from low estradiol concentrations and a consequently smaller LH surge, which could be associated with suboptimal luteinization of the growing CL after ovulation. This relationship has been found in primates (ZelinskiWooten et al., 1997). Studies in cows (Ambrose et al., 1998; Less et al., 1998; Rajamahendran et al., 1998) showed that an induced small LH surge was associated with inadequate postovulation plasma progesterone concentrations. Likewise, granulosa cells that were exposed to an inadequate or short-lived LH surge at the beginning of culture secreted less progesterone at the end of luteinization (Biger et al., 2000). An alternative reason for suboptimal progesterone secretion in these cows does not necessarily involve a small LH surge. A suboptimal CL could result from ovulation of a suboptimal preovulatory follicle, as indicated by the reduced concentrations of estradiol during the follicular phase in those cows. This hypothesis is supported by previous findings that a less-well-developed preovulatory follicle yielded a poor progesterone-secreting CL (Vasconcelos et al., 1999), and also that heat-stress-impaired follicles yielded poor progesterone-secreting CL (Wolfenson et al., 2002).

The likelihood that cows having the very long E-O intervals will conceive seems improbable for several reasons. First, as mentioned previously, the weaker association between time of $\mathrm{AI}$ and time of ovulation minimizes the probability of successful fertilization. Second, a small preovulatory LH surge may impair the normal process of resumption of meiosis and nuclear maturation (Tsafriri et al., 2005), and therefore could lead to development of an incompetent oocyte before ovulation. Third, cows with a long E-O interval exhibited low progesterone concentration curves, both before and after ovulation, which occasionally have been found to be associated with poor fertility (Kimura et al., 1987; Folman et al., 1990). These points are supported by a recent study (Kaim et al., 2003) in which lactating cows treated with $\mathrm{GnRH}$ at onset of estrus exhibited improved fertility. Greater conception was associated with 
induction of a shorter, less variable E-O interval, as well as with elevated postovulatory concentrations of circulating progesterone.

In conclusion, a group of cows with an extended EO interval was characterized by reduced concentrations of estradiol and a small LH surge before ovulation, and by low concentrations of progesterone before and after ovulation. The extended interval between estrus and ovulation, and the depressed hormonal secretions probably minimize the likelihood that these cows could conceive. No simple means exists presently to identify this group of cows that have an extended E-O interval. Therefore, hormonal treatments of cows having an extended E-O interval, intended to improve specifically their fertility, rather than general treatment of the whole herd, are currently not applicable to commercial herds, and further research is needed to achieve a suitable treatment. Such treatments include administration of $\mathrm{GnRH}$ at onset of estrus, or delaying the application of AI relative to time of estrus.

\section{ACKNOWLEDGMENTS}

The authors express their appreciation of the help given by the staff of the dairy farm in Kibbutz Naan, Israel, and to the USDA for the provision of bovine LH and bovine $\mathrm{LH}$ antibodies.

\section{REFERENCES}

Ambrose, J. D., M. F. Pires, F. Moreira, T. Diaz, M. Binelli, and W. W. Thatcher. 1998. Influence of deslorelin (GnRH-agonist) implant on plasma progesterone, first wave dominant follicle and pregnancy in dairy cattle. Theriogenology 50:1157-1170.

Badinga, L., M. A. Driancourt, J. D. Savio, D. Wolfenson, M. Drost, D. L. de la Sota, and W. W. Thatcher. 1992. Endocrine and ovarian response associated with the first wave dominant follicle in cattle. Biol. Reprod. 47:871-883.

Battaglia, D. F., A. B. Beaver, T. G. Harris, E. Tanhehco, C. Viguie, and F. J. Karsch. 1999. Endotoxin disrupts the estradiol-induced luteinizing hormone surge: Interference with estradiol signal reading, not surge release. Endocrinology 140:2471-2479.

Biger, E., D. Wolfenson, R. Mamluk, N. Levi, Y. Graber, and R. Meidan. 2000. Effects of LH 'surge' patterns on the steroidogenic capacity of bovine follicular cells luteinized in vitro. 14th Int. Congr. Anim. Reprod. Stockholm. 1:27. (Abstr.)

Cavalieri, J., I. Rubio, J. E. Kinder, K. W. Entwistle, and L. A. Fitzpatrick. 1997. Synchronization of estrus and ovulation and associated endocrine changes in Bos indicus cows. Theriogenology 47:801-814

Dransfield, M. B. G., R. L. Nebel, R. E. Pearson, and L. D. Warnick. 1998. Timing of insemination for dairy cows identified in estrus by a radiotelemetric estrus detection system. J. Dairy Sci. 81:1874-1882.

Flamenbaum, I., D. Wolfenson, and A. Berman. 1986. Cooling dairy cattle by a combination of sprinkling and forced ventilation and its implementation in the shelter system. J. Dairy Sci. 69:3140-3147.

Folman, Y., M. Kaim, Z. Herz, and M. Rosenberg. 1990. Comparison of methods for synchronization of estrous cycles of dairy cows. 2. Effects of progesterone and parity on conception. J. Dairy Sci. $73: 2817-2825$.
Hernandez-Ceron, J., L. Zarco, and V. Lima-Tamayo. 1993. Incidence of delayed ovulation in Holstein heifers and its effects on fertility and early luteal function. Theriogenology 40:1073-1081.

Hunter, R. H. F. 1994. Causes for failure of fertilization in domestic species. Pages 1-22 in Embryonic Mortality in Domestic Species. M. T. Zavy and R. D. Geisert, ed. CRC Press, Boca Raton, FL.

Kaim, M., A. Bloch, D. Wolfenson, R. Braw-Tal, M. Rosenberg, H. Voet, and Y. Folman. 2003. Effects of GnRH administered to cows at the onset of estrus on timing of ovulation, endocrine responses and conception rates. J. Dairy Sci. 86:2012-2021.

Kimura, M., T. Nakao, M. Moriyoshi, and K. Kawata. 1987. Luteal phase deficiency as a possible cause for repeat breeding in dairy cows. Br. Vet. J. 143:560-566.

Lavon, Y., G. Leitner, T. Goshen, M. Hogeg, R. Braw-Tal, M. Maman, S. Jacoby, and D. Wolfenson. 2004. Exposure to endotoxin during estrus or corpus luteum formation impaired reproductive functions in cows. J. Dairy Sci. 82(Suppl. 1):461. (Abstr.)

Lemaster, J. W., J. V. Yelich, J. R. Kempfer, and F. N. Schrick. 1999. Ovulation and estrus characteristics in crossbred Brahman heifers treated with an intravaginal progesterone-releasing insert in combination with prostaglandin $\mathrm{F}_{2 \alpha}$ and estradiol benzoate. J. Anim. Sci. 77:1860-1868.

Less, M., D. Wolfenson, A. Shaham-Albalancy, Z. Roth, and R. Meidan. 1998. Effects of LH surge patterns on progesterone secretion during development of the corpus luteum and in vitro luteinization of granulosa and theca cells in cows. J. Reprod. Fertil. 21:76. (Abstr.)

Mikeska, J. C., and G. L. Williams. 1988. Timing of preovulatory endocrine events, estrus and ovulation in Brahman $\times$ Hereford females synchronized with norgestomet and estradiol valerate. J. Anim. Sci. 66:939-946.

Mutayoba, B. M., H. H. D. Meyer, D. Schams, and E. Schallenberger. 1990. Development of a sensitive enzyme immunoassay for LH determination in bovine plasma using the streptavidin-biotin technique. Acta Endocrinol. (Copenh.) 122:227-232.

Nebel, R. L., M. G. Dransfield, S. M. Jobst, and J. H. Bame. 2000. Automated electronic systems for the detection of oestrus and timing of AI in cattle. Anim. Reprod. Sci. 60-61:713-723.

Rajamahendran, R., J. D. Ambrose, E. J. Schmitt, M. J. Thatcher, and W. W. Thatcher. 1998. Effects of buserelin injection and deslorelin (GnRH-agonist) implants on plasma progesterone, $\mathrm{LH}$, accessory CL formation, follicle and corpus luteum dynamics in Holstein cows. Theriogenology 50:1141-1455.

Renger, R. H., H. D. Hafs, J. H. Britt, and T. D. Carruthers. 1978. Luteolysis, growth hormone, glucocorticoids, prolactin and milk production in lactating dairy cows given prostaglandin F2 $\alpha$. J. Anim. Sci. 47:532-536.

Roelofs, J. B., E. G. Bouwman, S. J. Dieleman, F. J. C. M. van Eerdenburg, L. M. T. E. Kaal-Lansbergen, N. M. Soede, and B. Kemp. 2004. Influence of repeated rectal ultrasound examinations on hormone profiles and behavior around estrus and ovulation in dairy cattle. Theriogenology 62:1337-1352.

Roelofs, J. B., F. J. C. M. van Eerdenburg, N. M. Soede, and B. Kemp. 2005. Various behavioral signs of estrus and their relationship with time of ovulation in dairy cattle. Theriogenology 63:13661377 .

Saumande, J., and P. Humblot. 2005. The variability in the interval between estrus and ovulation in cattle and its determinants. Anim. Reprod. Sci. 85:171-182.

Shaham-Albalancy, A., Y. M. Rosenberg, Y. Folman, Y. Graber, R. Meidan, and D. Wolfenson. 2000. Two methods of inducing low plasma progesterone concentrations have different effects on dominant follicles in cows. J. Dairy Sci. 83:2771-2778.

Smith, M. W., and J. S. Stevenson. 1995. Fate of the dominant follicle, embryonal embryonic survival, and pregnancy rates in dairy cattle treated with prostaglandin F2 alpha and progestins in the absence or presence of a functional corpus luteum. J. Anim. Sci. 73:3743-3751.

Suzuki, C., K. Yoshioka, S. Iwamura, and H. Hirose. 2001. Endotoxin induces delayed ovulation following endocrine aberration during the proestrous phase in Holstein heifers. Domest. Anim. Endocrinol. 20:267-278. 
Tsafriri, A., X. Cao, H. Ashkenazi, S. Motola, M. Popliker, and S. H. Pomerantz. 2005. Resumption of oocyte meiosis in mammals: On models, meiosis activating sterols, steroids and EGF-like factors. Mol. Cell. Endocrinol. 234:37-45.

Vasconcelos, J. L. M., R. W. Silcox, G. J. M. Rosa, J. R. Pursley, and M. C. Wiltbank. 1999. Synchronization rate, size of the ovulatory follicle, and pregnancy rate after synchronization of ovulation beginning on different days of the estrous cycle in lactating dairy cows. Theriogenology 52:1067-1078.

Walker, W. L., R. L. Nebel, and M. L. McGilliard. 1996. Time of ovulation relative to mounting activity in dairy cattle. J. Dairy Sci. 79:1555-1561.
Wildman, E., G. M. Jones, P. E. Wagner, H. F. Troutt, and T. N. Lesch. 1982. A dairy cow body condition scoring system and its relationship to selected production characteristics. J. Dairy Sci. 65:495-501.

Wolfenson, D., H. Sonego, A. Bloch, A. Shaham-Albalancy, M. Kaim, Y. Folman, and R. Meidan. 2002. Seasonal differences in progesterone production by bovine luteinized thecal and granulosa cells. Domest. Anim. Endocrinol. 22:81-90.

Zelinski-Wooten, M. B., J. S. Hutchinson, I. Trinchard-Lugan, D. L. Hess, D. P. Wolf, and R. L. Stouffer. 1997. Initiation of periovulatory events in gonadotrophin-stimulated macaques with varying doses of recombinant human chorionic gonadotrophin. Hum. Reprod. 12:1877-1885. 